\title{
Partnership of Schools and Communities in the Era of the Industrial Revolution 4.0 in the Implementation of Alternative Education
}

\author{
Herlina, Suparno Eko Widodo, R. Madhakomala
}

\begin{abstract}
The Industrial Revolution 4.0 is an era which anything can be automatically assisted by machines. This affects schools and communities as parts of social life. Therefore, a firm partnership between those two parties are crucially needed particularly in providing alternative education. The present research aimed at analyzing varieties of school and communities partnerships in providing alternative schools at the senior high school level. A single case study research method was employed with two informants as the primary data source and sixteen informants as the secondary data source. The data were collected through open ended, in depth interviews, and direct observations. The result suggested that Master Learning Center collaborated with particular communities, is able to provide educational needs affecting students' achievement. This led to a general conclusion that schools-communities partnerships are considered an effective type of cooperation to supply the needs of schooling. The partnerships either assisted marginal society with the education quality improvement.
\end{abstract}

Index Terms: Schools-Communities Partnerships, Alternative Schools, Industrial Revolution 4.0.

\section{INTRODUCTION}

School-community partnerships play an essential role in successful schools, often providing supports and resources to meet staff, family, and student needs that go beyond what is typically available through school (1). Partnerships between schools and communities also have become current demands for recent education in the industrial revolution 4.0. It with its fast-paced and disruptive technology offers opportunities on the one hand and new challenges on the other hand (2). Intricate educational problems, due to internal and external factors, effectuate new policies, educator rules, strategies and methods as well. The implementation is also the result of regional autonomy realization, in which every region has different resource capacity.

Education is citizens' right to improve their quality of life. Qualified education is reckoned to be not only advantageous for people from higher economic level with their complete facilities, but should also be beneficial for those who come from remote and less developed areas, and/or kids affected by disasters and social calamity or children of the underprivileged. One of the efforts from

Revised Manuscript Received on April 19, 2019.

Herlina, Educational Management, Universitas Negeri Jakarta, DKI Jakarta, Indonesia.(Email: herlina_mp16s3@mahasiswa.unj.ac.id)

Suparno Eko Widodo, Lecturer in Educational Management Department-Universitas Negeri Jakarta, Indonesia.(Email: suparnoeko@unj.ac.id)

R. Madhakomala, Lecturer in Educational Management and Human Resource Management Department-Universitas Negeri Jakarta, Indonesia. (Email: madhakomala@unj.ac.id) government and communities to overcome this issue is organizing alternative education which enables to provide educational services for children coming from those mentioned criteria.

One of alternative education designs in formal education is Open School of Senior High School level, expected to increase the gross enrollment rate and lower the dropout rate in Indonesia. Based on the grand tour, the interview result with one informant in Master School revealed that the initiation of establishing the Open School was due to thoughtfulness of the founder of children future who had finished their education at Open School for junior high school level or Packet A (national elementary school equivalency examination) or B (national junior high school equivalency examination) in Master School and his willingness to support the government program "12-year Compulsory Education".

Master stands for Masjid Terminal. Master School was established in 2000 by Mr. RH who shows his concern over street children hanging around Depok the bus station. Today, Master School Indonesia managed by Foundation of Bina Insan Mandiri has established some levels of education ranging from Early Childhood Education, National Elementary School Equivalency Examination (Package A), National Junior High School Equivalency Examination (Packet B) and National Senior High School Equivalency Examination (Packet C) to higher education with Diploma 3 level.

Another uniqueness found is the learning process in Master School organized in 40 feet high cube container classes. The containers were donated by private companies or government organizations. Allured by the phenomenon and case mentioned above, the analysis of schoolcommunity partnerships to provide alternative education is performed. The researcher analyzed the result of research using alternative education, as a general term of various educational programs which carried out differently from general education.

\section{LITERATURE REVIEW}

Partnerships are defined as a common relationship formed in community, this kind of relationship is formed by interaction among community members for the sake of need-fulfilment. Partnerships in education field have been 
found to promote students' learning, empower schools and patronize struggling neighborhoods as well (3).

The theory of 'Overlapping Spheres of Influence', the basic theory of family-school-community partnerships in children education, acknowledges the basic principle that academic achievement of a child will be successfully accomplished by the partnership and support from his school, family and community (4). Partnerships among school and community members, families, organizations, and business enterprises should be well-planned and earnestly organized either directly or indirectly in order to embolden social, emotional, physical and intellectual development of students (5). Students should be the main concern in developing such partnerships for they are the center of schooling. Partnerships between school and community cannot be simply noticed for students' success at school only, but should also be aspired to strengthen, guide and motivate them.

Partnerships in education shall, at least, involve three components, parents (family), school, and community. The objective, to Epstein (6) is to promote school program and climate, provide service and family support, develop skills and leadership as parents, connect family and community at school, and assist teachers with their works. Moreover, school-community partnerships are considered to give influence to students' success and after school outcomes, positively influence and give advantages to the community in return as well (1).

Forming educational partnerships in democratic climate is inextricably intertwined with alignments to the unprivileged. On that ground, White and Wehlage (7) proclaim political strategies to persuade parties or other organizations taking sides of the underprivileged concerns would be rather preferable than to establish partnerships with emphases on program and professionalism. To this degree, the existing resource automatically will take the poor sides. As conceptualized by Maton (2008), empowered settings are those that offer marginalized populations, including youth, legitimate opportunities to gain greater control over their lives and environments (8).

Positive social changes have become a reality, because citizens benefit from informal partnerships between nonprofit organizations (NPOs) and government agencies, by the presence of opportunities for health and social services, education, career and job counseling, and other cultural and economic prospects (9). Forming partnerships with various societal structures is one of the innovative ways in which the environment for effective teaching and learning can be created and sustained. Research (10). This leads to partnership appearance in many organizations in the whole country. One of the most common with such relationships is educational institutions.

Some factors empowering school-community partnerships are leadership, commitment, school culture, collaboration and communication (1). Epstein (6) tends to conclude 6 types of partnerships among schools-familiescommunities, they are: parenting, communication, volunteer activities, students' instructional activities at home, decision making, and collaboration with community. Frederico (11) identifies several critical aspects to assist with the translation of general partnership goals into specific, clearly articulated actions by having a clear vision for the project, understood and committed to by all partners, is a first step. Meanwhile, leaders could develop a broad vision for school and community, positioned the school as a spatial community asset, championed community causes at the school, and changed school culture (12).

\section{METHODOLOGY}

The present research employed case study method. This assists the researchers with conducting an investigation (revealing a case chosen by the researchers based on facts found in the research setting) and persevering holistic characteristics and meaningfulness of real events occurring at school-community partnerships to provide alternative education.

The research was conducted in Master Learning Center, located precisely beside Depok Bus Station, East Java, Indonesia. This 2018-2019 research employed three techniques of data collection. The first was interviews; the researcher determined key informants who knew well the substance of research foci, they were: SR as the senior high school manager in Master School. As the secondary data source, snowball and purposive sampling technique were applied. They consisted of RH as the supervisor of Master School, MT as the chairman of the foundation, the principal of Open Secondary School, partners of Master Learning Center, and 14 tutors. The second technique implemented was direct observations, and the last was relevant document analysis.

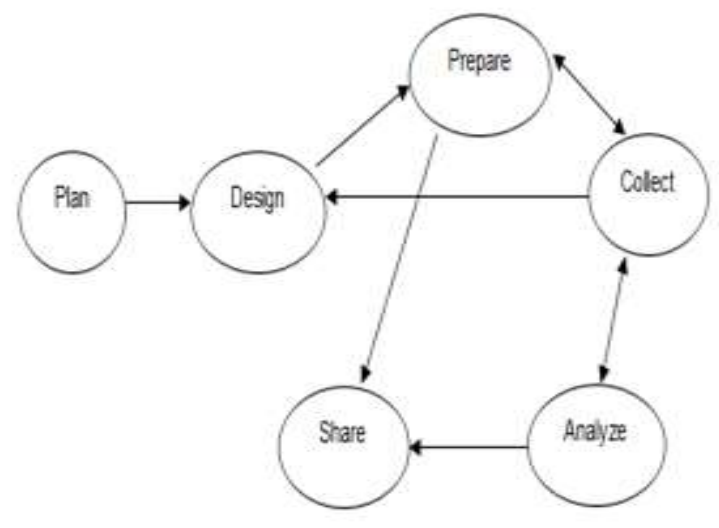

Figure 1. Case Study Research

The research illustration with case study method figure above was carried out several times like a cycle. It started from planning by creating research outline as a guidance in collecting, analyzing and interpreting data. The data were then presented in narration, pictures, figures and other relevant forms. The researcher, in detail, adopted what those mentioned in the following figure: 

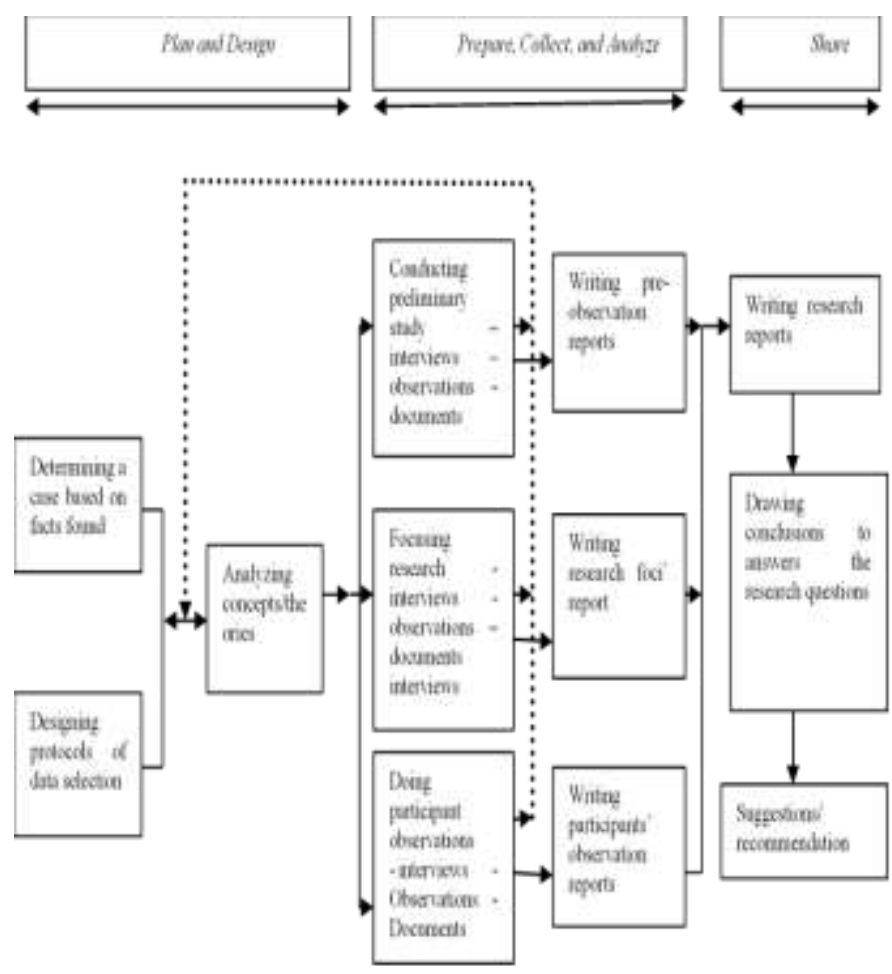

Figure 2. Case Study Method

The present research applied the following procedure:

First, the researchers went for a grand tour by administering interviews, observations and document analysis. Afterwards, the data collected were analyzed by raw data presentation, reduction (sorting, simplifying, and abstracting the data based on the facts identified in the research setting, they were then categorized and coded to help the researchers draw the conclusions). The next stage to apply was presenting the data in narration, images, figures and other relevant forms. The data were then interpreted (comparing the concept and previous research findings then giving them meaning), and the grand tour report was jot down.

Second, the researcher sharpened the research foci by carrying out a mini tour observation using the data collection technique set in advance (interviews, observations and document analysis). The data gained were then analyzed by applying the technique suggested by Miles and Huberman, consisting of presenting raw data, data reduction, data interpretation, and writing a report on problem limitation.

Third, the researcher conducted participant observations by playing a role as a volunteer tutor in the research setting for several months. The similar technique of data collection and data analysis were applied in this step. The researcher then reported the participant observations.

Fourth, having finished the three steps, the researcher then combined the whole reports, drew conclusions by verifying the data validity and formulated conclusions as the answers to the research questions, then proposed recommendations.

\section{RESULTS AND FINDINGS}

One of the partnerships form created by school and community is the partnership between Open School of 4 and
Master Learning Center. Open School of 4 has three learning centers, Learning Center of 4, Master Learning Center and Mentari Cendikia Learning Center. Learning Center is a place provided by the community at which learning activities take place. Learning Center may utilize schools, mosques, halls, factories, or rooms which can be functioned as learning place for the students.

Among those three, Master Learning Center is the most frequent place visited by people to conduct research due to the uniqueness mentioned in advance. Master Learning Center also collaborates with some students from Faculty of Economics and Islamic Business from state universities to accommodate education service for the students. Not only that, the management of Master Learning Center has another partnership with community to equip the students with life skills. Some of them are cooking class called as "cooking community", beauty class shared by "private company", social media workshop in collaboration with students from private universities and teachers for computer and English subject provided by private university lecturers.

As an alternative school, Master School led by Mr. RH works in a synergy with a number of community elements. Community consisting of both individuals and groups, either profitable or non-profitable organizations, works collaboratively with Master School providing qualified educational services for marginal people. The following data unveil the success of partnership program in sending the students to higher education.

Table 1. Students of Open Secondary School 'Master' Accepted in State Universities in 2018

\begin{tabular}{|c|c|c|c|c|}
\hline №. & Name & $\begin{array}{l}\text { Admission } \\
\text { Channel }\end{array}$ & University & Major \\
\hline 1. & $\mathrm{AF}$ & $\begin{array}{l}\text { State University } \\
\text { National } \\
\text { Entrance Exam }\end{array}$ & $\begin{array}{l}\text { State University in } \\
\text { Jakarta }\end{array}$ & $\begin{array}{l}\text { Educational } \\
\text { Management }\end{array}$ \\
\hline 2. & $\mathrm{AK}$ & $\begin{array}{l}\text { Religion State } \\
\text { University } \\
\text { National } \\
\text { Entrance Exam }\end{array}$ & $\begin{array}{c}\text { Religion State } \\
\text { University in Jakarta }\end{array}$ & $\begin{array}{c}\text { Islamic } \\
\text { Education Study } \\
\text { Program }\end{array}$ \\
\hline 3. & MUK & $\begin{array}{c}\text { Religion State } \\
\text { University } \\
\text { National } \\
\text { Entrance Exam }\end{array}$ & $\begin{array}{c}\text { Religion State } \\
\text { University in Jakarta }\end{array}$ & $\begin{array}{c}\text { Sharia } \\
\text { Economics }\end{array}$ \\
\hline 4. & ANN & $\begin{array}{c}\text { State University } \\
\text { Joint Entrance } \\
\text { Exam }\end{array}$ & $\begin{array}{l}\text { State University in } \\
\text { Jakarta }\end{array}$ & $\begin{array}{l}\text { Culinary Art } \\
\text { Vocational } \\
\text { Education }\end{array}$ \\
\hline 5. & JFA & $\begin{array}{c}\text { State University } \\
\text { Joint Entrance } \\
\text { Exam }\end{array}$ & $\begin{array}{l}\text { State University in } \\
\text { Depok }\end{array}$ & $\begin{array}{l}\text { Javanese } \\
\text { Literature }\end{array}$ \\
\hline 6. & RNR & $\begin{array}{c}\text { State University } \\
\text { Joint Entrance } \\
\text { Exam }\end{array}$ & $\begin{array}{l}\text { State University in } \\
\text { Jakarta }\end{array}$ & $\begin{array}{l}\text { Sociology } \\
\text { Education }\end{array}$ \\
\hline 7. & RMJ & $\begin{array}{c}\text { State University } \\
\text { Joint Entrance } \\
\text { Exam }\end{array}$ & $\begin{array}{l}\text { State University in } \\
\text { Jakarta }\end{array}$ & $\begin{array}{c}\text { Arabic } \\
\text { Education }\end{array}$ \\
\hline
\end{tabular}

\subsection{Partnership Types}

One of partnership activities between Master Learning Center and the community around it is academic tutoring course service. Master Learning Center as a part of open schools affiliated to Open School of 4, also works together with some universities to organize the learning process. Based on the interview result, one informant argued, "Here we have intensive tutoring course from State University, the Faculty of Economics and Business. We were taught for one 
year by the students." (interview translated version). This reveals one of the interesting partnerships managed by Master Learning Center and faculty of state university to provide intensive academic guiding for the students for one year. Two kinds of guiding are noticed: 1) regular tutoring course run in the evening in Master Learning Center and 2) intensive tutoring course held daily in the library of state university. AN, another informant strengthened the findings.

"Yes, there are some steps to pass state university intensive tutoring course. Here we have 2 kinds of academic tutoring course. One is organized after school in Master, the intensive one is held every day in state university library. To join the intensive course, we need to pass 4 steps. Our first step at class, we are observed, and then we have academic tests, and the last is interview." (interview translated

The interviews uncover four steps of intensive tutoring course selection, which are: a) registration; b) observation; c) written test; and d) interview. This further means that not all students in Master Learning Center can join the intensive tutoring course in the faculty of state university. The selection was intended not only to select the students whose excellent academic competence, but also to determine those whose high motivation to continue study to higher education.

Collaborations among tutors are either from state or private universities, also completed by people individually, for instance, Mr. SB, an ex NGO employee.

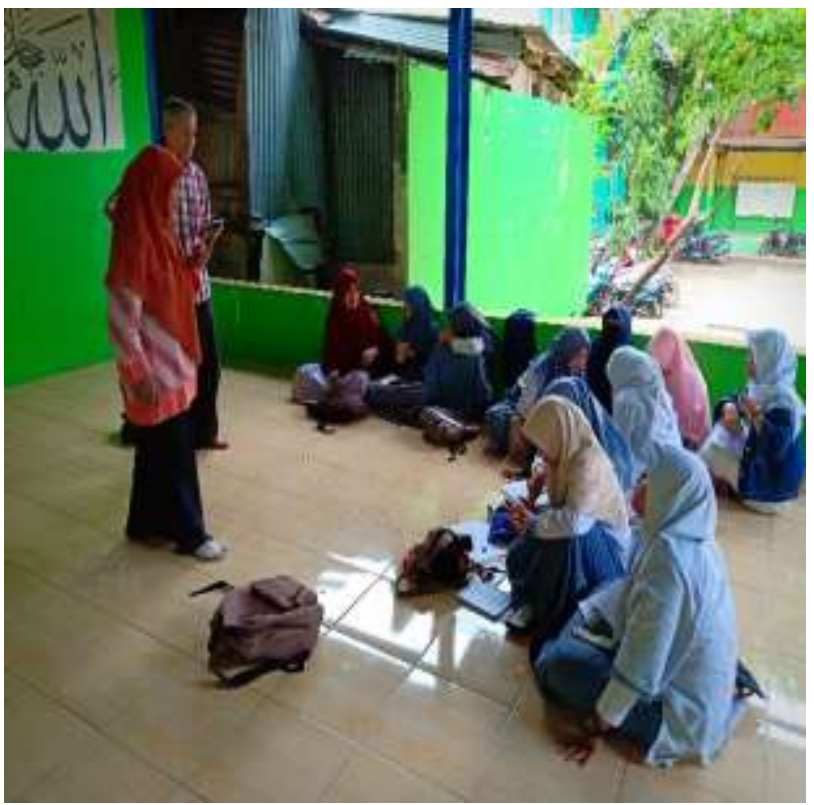

Figure 3. Collaborations of volunteer tutor with Master tutor

The picture above depicted Mr. SB and Mrs. ST collaboration to teach English in 2nd grade of Mandiri Putri class. They had the session in Master prayer room (mushola) with few facilities. Mr. SB voluntarily taught three times in a week. Master Learning Center's management offered him a pre-requisite to teach at least for one semester. The management imposed on this regulation as an effort to decrease volunteer tutor turnover rate.

In another occasion, the researcher was also present in computer class taught by RZ, an alumnus of Master version)

Learning Center. Alumni, as a part of communities, contribute their knowledge for the students in Master. As an alumnus, RZ personally felt responsible towards the learning process in Master the place where he studied. Having graduated from one state university, RZ made his time for teaching computer skills to his juniors. This fact is in line with what mentioned by White and Harris (13) that partnerships might also be established as the presence of feel of belongings for the process and result of unlimited benefit so that it is depicted as the starting point of collaboration.

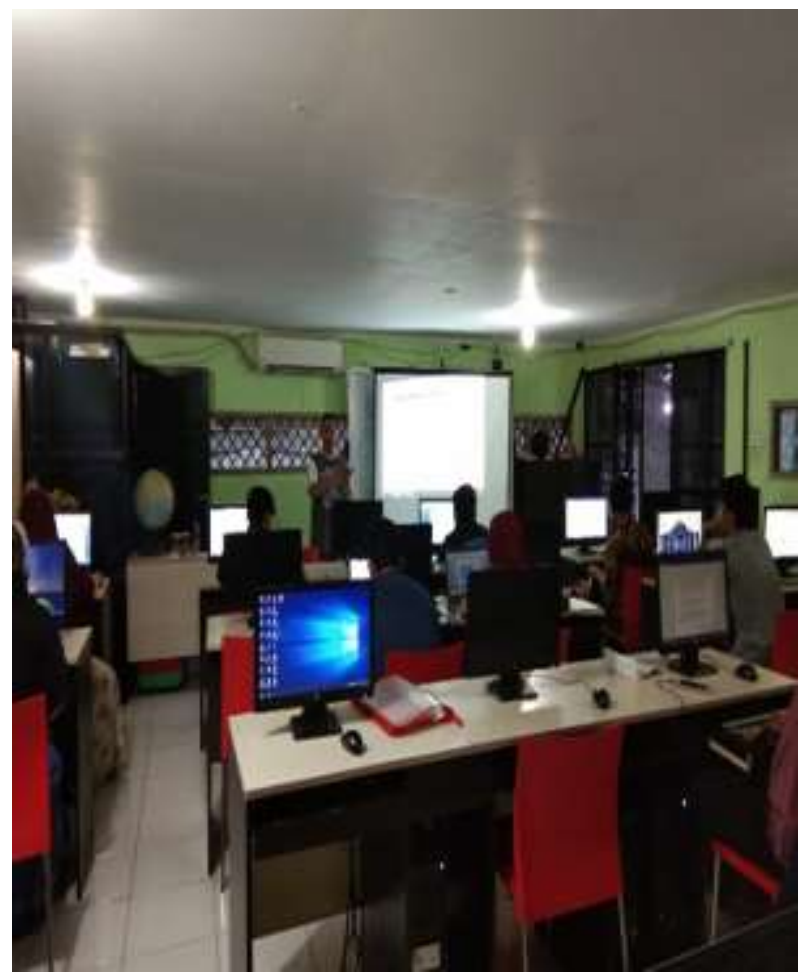

Figure 4. Computer class run by an alumnus

Community consists of people who are interested and possess willingness to share benefits for education quality, not only for the matter that their kids are going to schools. This is in agreement with Epstein (6), that those who give contribution to education are both people surrounding the schools or students' home, and people who influence learning and students' development. Principally, communities are not decoded by the social and economic status; remarking them by their strength and skills to patronize students, families and schools are more preferable.

In this context, community refers to not only people reside around the school. Moreover, they may not have school-age kids but show interest in schooling, or people in one region with kinship (14). This further infers that community is not geographically limited to school environment, but more appertaining to social interaction occurring in the community or with people in the surroundings.

The following table shows some collaborations between Master Learning Center and some relevant communities. 
Table 2. Master Learning Center Collaborates with Some Communities in 2013-2019

\begin{tabular}{|c|c|c|c|}
\hline No. & Program and Activity & Partner & Partnership Type \\
\hline 1. & $\begin{array}{l}\text { Infrastructure supply } \\
\text { (container) }\end{array}$ & State-owned Enterprise & Non academic \\
\hline 2. & $\begin{array}{l}\text { Infrastructure supply } \\
\text { (container) }\end{array}$ & State-owned Enterprise & Non academic \\
\hline 3. & $\begin{array}{l}\text { Infrastructure supply } \\
\text { (container) }\end{array}$ & Private Enterprise & Non academic \\
\hline 4. & $\begin{array}{l}\text { Salon, fashion design, } \\
\text { reflexology, and make up } \\
\text { training }\end{array}$ & Private Enterprise & Academic \\
\hline 5. & Operational donation & State-owned Enterprise & Non academic \\
\hline 6. & Cooking class & 'CD' Community & Academic \\
\hline 7. & Operational donation & $\begin{array}{l}\text { World Funding } \\
\text { Foundation }\end{array}$ & Non academic \\
\hline 8. & $\begin{array}{l}\text { Community Service } \\
\text { (national examination } \\
\text { enrichment) }\end{array}$ & Private University & Academic \\
\hline 9. & $\begin{array}{l}\text { FEB UI-Master } \\
\text { Intensive and regular } \\
\text { tutoring course }\end{array}$ & State University & Academic \\
\hline 10. & Drug counseling & State University & Academic \\
\hline 11. & Communication Fair & Private University & Academic \\
\hline 12. & $\begin{array}{l}\text { Women Health } \\
\text { Counseling }\end{array}$ & State University & Academic \\
\hline 13. & $\begin{array}{l}\text { History Recognition } \\
\text { Movement }\end{array}$ & State University & Academic \\
\hline 14. & $\begin{array}{l}\text { Hydrogen Zero Emission } \\
\text { Mobility \& Education for } \\
\text { Asian Games }\end{array}$ & State University & Academic \\
\hline 15. & $\begin{array}{l}\text { Sound Internet } \\
\text { Counseling }\end{array}$ & Private University & Academic \\
\hline 16. & $\begin{array}{l}\text { Counseling of teenager } \\
\text { reproductive health }\end{array}$ & Private University & Academic \\
\hline 17. & $\begin{array}{l}\text { Drug and health } \\
\text { counseling }\end{array}$ & Private University & Academic \\
\hline 18. & Infrastructure renovation & Private enterprise & Non academic \\
\hline 19. & $\begin{array}{l}\text { Infrastructure supply } \\
\text { (solar cells) }\end{array}$ & $\begin{array}{l}\text { State University- State- } \\
\text { owned Enterprise }\end{array}$ & Non academic \\
\hline 20. & $\begin{array}{l}\text { Urban farming } \\
\text { counseling }\end{array}$ & $\begin{array}{l}\text { State University- } \\
\text { Community }\end{array}$ & Academic \\
\hline
\end{tabular}

The above table points out that Master Learning Center are either collaborated with the communities for academic or non-academic matters, case in point, infrastructure and operational finance. The communities provide resources of necessity to support learning activities at the school. Some of those resources need funds for the maintenance and some other do not. Schools as the party that make use of the resources are required to be able to identify and optimally use them for educational concern.

\subsection{Partnership Challenges}

In knitting partnership with the communities, Master Learning Center receives facility but at the same time challenges come. One of the challenges is tailoring all partnership types to Master's seven values. One of the volunteer tutors asserted, "We have seven values as the basic of conducting any activity in Master. Those also become the standard we apply when some partners come to contribute." The seven values are: 1) belief; 2) togetherness; 3) care; 4) hygiene and environmental sustainability; 5) obedience; 6) harmony; and 7) independence.

$\mathrm{NN}$ further professed that goal miscommunication and implementation are some of the challenges they encounter in the partnerships. Master expects that the partnerships woven refer to Master's vision and mission so that the program implemented stays in the same corridor. Another challenge arisen from internal factor, that $\mathrm{Mr}$. $\mathrm{RH}$ as the Master founder, applies an informal partnership type. He claimed,

"There is no fixed procedure, it is free. Feel free. Just do what you wish, even selling drugs is okay if you want, as long as nobody knows it. People come here with their good will. Why should we disallow them or mistrust them bringing something bad. Any wrong doing will be their own business. Most bureaucrats make everything complicated at the beginning, suspect somebody with something. That's troublesome. They accuse people first, what student are you, communist, Muhammadiyah or Syiah, so upsetting. People are doubted from the beginning."

Further, he declared,

"Documents are not important for me. I am not a celebrity, what advantage can you take from me? What you need, deed are hidden. For people, with this Ambassador, with this Minister, is important. For me, what is that for? For rice wrapper. I do not pin them (pointing at certificates pinned on his wall's room). I just pile them up."

His explanation symbolizes how he takes no heed of bureaucracy. Meanwhile, this case becomes a crucial issue in another educational institution. Applying informal partnerships directs Master to have no standard procedure of knitting partnerships with community. This is a contradictory fact compared to other educational institutions employing standard procedure or facilitating a partnership $\mathrm{MoU}$ as a proof that their institutions have once collaborated with particular community.

One of Master's partners, HN, admitted this condition, "Oo, at first, I don't know, ma'am. From DD or NF, no MoU to sign." Even when the researcher asked for MoU documents with some institutions, only old documents were handed. In the contrary, the MoU partnership documents with state and private universities were not found.

In short, partnership challenges collaboratively can be solved by performing positive and open leadership to all community elements so that people may come to collaborate freely with Master Learning Center. In this point, Master Learning Center indicates their informal partnerships, intertwined by a non-binding agreement and not officially molded it into cooperation agreement documents. They preferred cooperative realization, togetherness, and respect one to another, for instance, inviting each other to seminars, workshops, and partnership institutional visits. This informal partnership realization may change or be stopped due to leader commutation or policy changes of the related parties.

\subsection{Partnerships Strategies}

Partnerships strategies performed by Master with community are as follows:

a. Involving volunteer tutors. They have 14 tutors recently, coming from community who care about education for the marginal and most of them are alumni of Master Learning Center. From 12 of them filling the questionnaires for demographic data, it is identified that $41,7 \%$ of them are the alumni, and 58,3\% are not. 
International Conference on Recents Advancements in Engineering and Technology (ICRAET-18) |15th and 16th March 2019|Siddhartha Institute of Technology \& Sciences, Telangana, India.

Table 2. Demographic of Volunteering Tutors in Master Learning Center

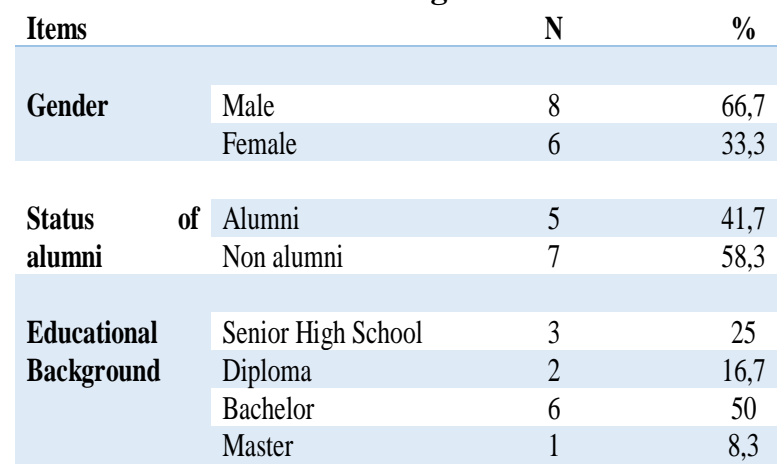

They are the educational volunteers whose hearts are moved to contribute their knowledge to their surroundings. Without being paid by the foundation or school, they keep dedicating themselves to teach in Master Learning Center whose students come from the unprivileged. Master Learning Center for senior high school level does not collect tuition fee at all except for diploma photo.

b. Visiting partners directly. As mentioned by one informant, $\mathrm{RH}$, "We need to come to visit first, if the students have problems with law, we make the school there. In such a jail. If our country supports this activity, no need for Master to do this." The strategy applied is collaborating with the penitentiary to deliver learning service outside Master Learning Center's area itself. If the jailed kids do not accept sufficient education, they will have no provision to face the competitive world after being released from the jail. They will feel lonely, have no ability for self-actualization in civilization life, feel stupid and left-behind so that isolation and no more acceptance from society are fiercely possible to happen. Those reasons have Master broaden their scope of collaboration to juvenile jails.

c. Communicating partnership activities in social media and online mass media. Instagram and line are state university Master and Master School Indonesia's social media platform delivering information of the students' acceptance in state universities via state university national entrance exam and state university joint entrance exam $@$ masterfebui. All activities are posted in the social media and some media had once covered the news to broadcast the information as a form of Master's responsibility to public.

d. Improving collaboration with other educational institutions to empower human resources, especially volunteer tutors. MT as the key informant corroborated this, human resources. This is why in every meeting or nonformal discussion, we emphasize on the understanding of Master's seven values. We organize character study for our students. We also carry out curriculum, technology information trainings. Quantitatively, we try to cover the needs of tutors by having cooperation with other educational institutions. By augmenting freelance partnership, of course. We also try to upgrade the volunteer quality as a must for our pro-active actions. For example, when we had a cooperation with world funding foundation to enhance ICT skills. This room and the computers are their donation."
"To improve the quality, we here need to empower the

e. Arranging internship programs for Master students. Proving this, MT expressed,

"Yes, we have a plan for internship programs. Such as in a company or workshop. Although we are not from vocational schools, but they also need volunteering. This will train them to enter a workplace. Not all pupils here are academically bright. We direct the good ones to join tutoring in state university and prepare for university entrance exams. But for those whose less potential are also prepared."

\subsection{Discussion}

The demonstration of collaboration between Master Learning Center and wider community is a pivotal factor of fabricating forceful partnerships. Collaboration here refers to an act of working together on a new program by giving suggestions or new ideas accompanied by energy contribution during the instructional process. The assurance of reciprocal benefits for community partners are also granted by the collaboration. The collaboration among Master learning center and wider communities face miscommunication and implementation to achieve the school's goals. This is due to one main principle, that partnerships between school and communities enable more secure school environment, strengthen parenting skills, promote community service, foster academic skills, and reach another beneficial goal for students (5) (6).

Meanwhile, communication among partners plays decisive roles as well in collaboration. The communication needed should be performed openly and carried through all partners as it basically involves all partners to listen to each other (1). By social and mass media, Master Learning Center regularly share their partnership activities to community. That is either considered as responsibility or an insight for other volunteers willing to work together with Master Learning Center to accomodate alternative education for the marginal society.

Collaboration between schools and community allows a synergy to overcome problems by sharing responsibilities, funding, teachers and educators and places to collaborate (6). On that ground, imparting Master Learning Center's programs, such as educational partnership, to people is highly possible. Master Learning Center also offers components of community a chance to participate in partnership programs, by all means, contribution adjustment to school goals and student needs are notable. This is due to the essence of partnerships as a relationship between school and community members, families, organizations, and business enterprises, which ought to be planned and implemented earnestly, directly or indirectly, to enable social, emotional, physical and intellectual promotion of the students (6).

\section{CONCLUSION}

Open Secondary School of 4 Depok and Master Learning Center are a type of partnership between a state school and community in providing alternative education. The 
partnership both assists with the completion of 12-year Compulsory Education and enables access for the marginal to have qualified education until university level.

Besides knitting partnerships with the state school, Master Learning Center collaborates with wider community, either individuals or groups in academic or non-academic fields. However, Master Learning Center encounters obstacles; miscommunication of school goals with the partners and informal partnerships are problematic so that there is no standard guidance of partnerships applied. This leads to less trust of public to the partnerships knitted.

However, by the execution of some partnership strategies, such as recruiting volunteer tutors whose care about education, visiting partners directly, communicating with community via social and mass media, constructing wider collaboration either for the tutors or the students, Master Learning Center attempts to create partnerships which expected to meet the marginal student academic needs. This leads to a conclusion that collaboration is an effective school and community partnership type to provide alternative education in the era of the industrial revolution 4.0.

\section{ACKNOWLEDGEMENTS}

I gratefully thank to:

Universitas Negeri Jakarta, Indonesia

STKIP Kusuma Negara, Jakarta, Indonesia

Master Learning Center-Depok, East Java, Indonesia

Indonesia Endowment Fund for Education as the Proponent of Lecturers' Scholarship.

\section{REFERENCES}

1. Gross JMS, Haines SJ, Hill C, Grace L, Blue-banning M, Turnbull AP. Strong School - Community Partnerships in Inclusive Schools Are "Part of the Fabric of the School .... We Count on Them ." Sch Community J. 2015;25(2):9-34.

2. Abdul G, Maulani F, Hamdani NA. The Influence of Information Technology and Organizational Climate on the Competitiveness of Private Universities in Indonesia. Int J Recent Technol Eng ISSN. 2019;8(1):142-5.

3. Valli L, Stefanski A, Jacobson R. Typologizing School Community Partnerships: A Framework for Analysis and Action. Urban Educ. 2014;1-29.

4. Epstein JL. School, family, and community partnerships in teachers ' professional work professional work. J Educ Teach [Internet]. 2018;7476:1-10. Available from: https://doi.org/10.1080/02607476.2018.1465669

5. Sanders MG. COMMUNITY INVOLVEMENT IN SCHOOLS. Educ Urban Soc [Internet]. 2003;35(2):16180. Available from: 10.1177/0013124502239390

6. Epstein BJL. School/Family/Community Partnerships Community Family/ CARING FOR THE CHILDREN WE SHARE This. Kappanmagazine.org. 2009;81-97.

7. White JA. Community Collaboration: If It Is Such a Good Idea , Why Is It so Hard to Do ? Educ Eval Policy Anal. 2015;17(1):23-38.

8. Zeldin S, Gauley JS, Barringer A, Chapa B. How High Schools Become Empowering Communities: A MixedMethod Explanatory Inquiry into Youth-Adult Partnership and School Engagement. Am J Community Psychol. 2018;1-14.

9. Pozil S. Informal Partnerships Between Nonprofits and Local Governments and the Role of Trust. J Soc Chang. 2017;9(1):67-76.
10. Bhengu TT, Svosve E. Transforming Education Through School- Community Partnerships: Lessons from Four Rural Early Childhood Development Schools in Zimbabwe Transforming Education through Schoolcommunity Partnerships : Lessons from Four Rural Early Childhood Development Schools in Zimbabwe. 2018;6627(May).

11. Frederico M, Whiteside $M$, Frederico $M$, Whiteside $M$. Building School, Family, and Community Partnerships : Developing a Theoretical Framework. 2016;0748(December 2015).

12. Green TL. Leading for Urban School Reform and Community Development. Educ Adm Q. 2015;51(5):679-711.

13. White V and JH, editor. Developing Good Practice in Community Care-Partnership and Participation. London and New York: Jessica Kingsley Publishers Ltd; 2001.

14. Henderson AT, Mapp KL, Mapp KL, Buttram J. A New Wave of Evidence A New Wave of Evidence. Austin Texas; 2002.

\section{AUTHORS PROFILE}

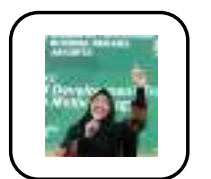

Herlina Undergraduate-STBA LIA, Postgraduate (Master and Doctoral) of Educational ManagementUniversitas Negeri Jakarta, Lecturer in English Education Study Program-STKIP Kusumanegara. email: herlina_mp16s3@mahasiswa.unj.ac.id

SINTA ID: 6081926

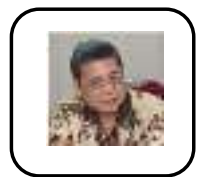

Suparno Eko Widodo Undergraduate-Universitas Negeri Malang, Postgraduate (Master and Doctoral)Universitas Negeri Jakarta, Lecturer in Educational Management Department-Universitas Negeri Jakarta. Email: suparnoeko@unj.ac.id

SINTA ID: 6031998

R. Madhakomala Undergraduate-Postgraduate (Master and Doctoral)-Universitas Negeri Jakarta, Lecturer in Educational Management and Human Resource Management Department-Universitas Negeri Jakarta. Email: madhakomala@unj.ac.id SINTA ID: 6024105 